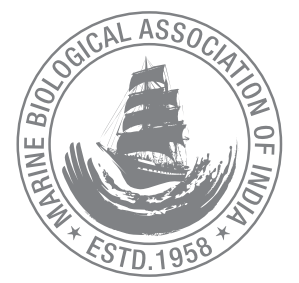

\title{
Fish Consumption: Gauging the determinants of consumption and buying patterns across Kerala markets
}

\author{
Shyam S. Salim*, S. Monolisha and P. V. Sunil \\ ICAR-Central Marine Fisheries Research Institute, Kochi - 682 018, Kerala, India. \\ *Correspondence e-mail: shyam.icar@gmail.com
}

Received: 19 Sep 2019 Accepted: 19 May 2020 Published: 25 May 2020

\begin{abstract}
Fish marketing is an efficient economic production system which depends on several multi-level market functionaries from producers to consumers. The perfect model of fish market systems entails continuum in flow of the goods and services with high level of customer satisfaction. With this viewpoint, the current study was focused on analysing the different types of domestic fish markets across 14 districts of Kerala. The objective of the study is to quantify different market attributes such as type of domestic fish markets, frequency of fish consumption by consumers, source of purchase, access to the markets and consumers' perception to choose markets according to their seafood requirements. Moreover, the current work was also focused towards analysing the opinions of consumers on buying fish while travel and travelling to buy fish. About 355 fish consumers (77\% Male and 23\% Female) from 82 registered domestic fish markets were interviewed based on the random sampling technique. The fish marketing network of three types of markets such as wholesale, retail and landing centre markets were studied in detail. From the geographical origin and settings, the markets were categorised into three namely, coastal markets, noncoastal markets and high-range markets. The study found that $65 \%$ of the respondents buy fish while travelling on hunch for ease. The inclination of fish buy amongst the respondents were higher from the retail markets (179) followed by way-side stalls (80) and vendors
\end{abstract}

(71). The fish consumption rate among the 355 respondents comprised of $45 \%$ of daily-fish eaters, $33 \%$ alternative day eaters followed by biweekly (12\%), weekly (8\%) and fortnightly $(2 \%)$. The fish marketing channels varied across the different type of markets. However, the marketing efficiency was lowest in the registered domestic markets whereas it was highest in the unregistered wayside stalls. On the other hand, marketing efficiency is also influenced the preference of choosing fish markets for procurement across the respondents. The market infrastructure of unregistered way-side stalls was observed to be poor in terms of fish handling, icing, packaging, and cold storage and transportation facilities. The study also identified the constraints experienced by the registered fish markets and also recorded specific policy recommendations to be implemented in Kerala fish markets to efficiently transmute both the registered domestic fish markets and unregistered way-side stalls.

Keywords: Fish markets, consumption, Kerala, buying pattern, marketing channels, consumers

\section{Introduction}

Marine fishery of Kerala has grown sustainably and serves as an important source of the livelihood to the coastal 
communities of the region. Both the marine and inland fishery resources from the state contributes to the hovering economy of the country and are known for the export and import of processed and post-harvested seafood and sea-food allied products. Amongst these solid resilient topographic and socio-economic settings, Kerala has drawn attention for its local fish markets which embroils contrasting market structures, channels and functionaries varying with localities and whereabouts. Every which way, the spontaneous glance of any market place will be with stalls and crowds of sea food varieties and alarming noises raised by sales personnel. Any local consumers visit these fish markets for fresh purchase with extra skills as a shrewd shopper towards the price and quality of the products.

In India, domestic fish marketing system is carried out by private traders with multiple intermediaries from producers to consumers. Several studies reported on different species marketed, market structures, conduct, performance and the policies of fish marketing in India (Sathiadhas and Narayanakumar, 1994; Kumar et al., 2008; Shyam et al., 2010; Shyam and Rahman, 2014; Aswathy et al., 2017) However, detailed studies on comparisons among the different domestic fish markets and consumer preferences to these markets and policy recommendations implementing proper marketing functionaries to the local-way-side stalls are poorly studied (Vanhonacker et al., 2010). Fishes are heterogeneous commodities that vary across space and time with respect to their size, quality, quantity and price. Based on the above conditions, consumer perception on choosing a suitable domestic fish market to buy fishes are contrasting to every purchaser (Shyam et al., 2015; Shyam et al., 2016)

The market study has been conducted in all the major coastal states and some selected inland states to understand the domestic marketing of fish in India. The total marketing costs of auctioneer, wholesaler, retailer, vendor, marine fishermen cooperative society and contractor/freshwater fishermen cooperative society have been found to be Re 0.98 , Rs 8.89, Rs 6.61, Rs 4.50, Rs 6.00 and Rs 3.51, respectively. The marketing efficiencies for Indian major carps (IMC. However, detailed studies on comparisons among the different domestic fish markets and consumer preferences to these markets and policy recommendations implementing proper marketing functionaries to the local-way-side stalls are poorly studied (Vanhonacker et al., 2010). Fishes are heterogeneous commodities that vary across space and time with respect to their size, quality, quantity and price. Based on the above conditions, consumer perception on choosing a suitable domestic fish market to buy fishes are contrasting to every purchaser (Shyam et al., 2015; Shyam et al., 2016).
This study was designed to have a snap-shot of the prevailing domestic fish marketing scenario along the different states of Kerala. The work was focused on quantifying the types of domestic fish markets, frequency of fish consumption by consumers, source of purchase, access to the markets, consumers' perception to choose markets according to their seafood necessities. These parameters were quantitatively analysed across all the districts which includes coastal areas, inland areas and high-range areas of Kerala. Recommendations and policy implications hinged on to improve these domestic fish markets were also discussed.

\section{Material and methods}

The study was carried out during the period of MarchMay 2019 for getting an account of fish marketing system across all the 14 districts of Kerala. Table 1 represents the market locations and Fig. 1 presents the districts of the markets surveyed. About 82 different domestic fish markets

\begin{tabular}{|c|c|c|c|c|c|}
\hline $\begin{array}{l}\text { Sl. } \\
\text { No. }\end{array}$ & Market & District & Type of Area & $\begin{array}{l}\text { Type of } \\
\text { Market }\end{array}$ & Lat-Long \\
\hline 1. & Chavakkad & Thrissur & Coastal & WM & $\begin{array}{l}10.5833^{\circ} \mathrm{N} \\
76.0189^{\circ} \mathrm{E}\end{array}$ \\
\hline 2. & Vadanapilly & Thrissur & Coastal & WM & $\begin{array}{l}10.4730^{\circ} \mathrm{N}, \\
76.0682^{\circ} \mathrm{E}\end{array}$ \\
\hline 3. & Kunnamkulam & Thrissur & Coastal & WM & $\begin{array}{l}10.6516^{\circ} \mathrm{N} \\
76.0711^{\circ} \mathrm{E}\end{array}$ \\
\hline 4. & Ponnani & Malappuram & Coastal & WM & $\begin{array}{l}10.7677^{\circ} \mathrm{N}, \\
75.9259^{\circ} \mathrm{E}\end{array}$ \\
\hline 5. & PonnaniChamrtavattiom & Malappuram & Coastal & WM & $\begin{array}{l}10.8171^{\circ} \mathrm{N}, \\
75.9608^{\circ} \mathrm{E}\end{array}$ \\
\hline 6. & Edappal & Malappuram & Non-coastal & WM & $\begin{array}{l}10.7839^{\circ} \mathrm{N} \\
76.0076^{\circ} \mathrm{E}\end{array}$ \\
\hline 7. & Valancherry & Malappuram & Non-coastal & RM & $\begin{array}{l}10.8877^{\circ} \mathrm{N} \\
76.0738^{\circ} \mathrm{E}\end{array}$ \\
\hline 8. & Kottakal & Malappuram & Non-coastal & RM & $\begin{array}{l}11.0001^{\circ} \mathrm{N}, \\
75.9988^{\circ} \mathrm{E}\end{array}$ \\
\hline 9. & Thirur & Malappuram & Non-coastal & WM & $\begin{array}{l}11.0510^{\circ} \mathrm{N}, \\
76.0711^{\circ} \mathrm{E}\end{array}$ \\
\hline 10. & Malappuram & Malappuram & Non-coastal & WM & $\begin{array}{l}11.1203^{\circ} \mathrm{N} \\
76.1200^{\circ} \mathrm{E}\end{array}$ \\
\hline 11. & Perinthalmanna & Malappuram & Non-coastal & WM & $\begin{array}{l}11.1203^{\circ} \mathrm{N} \\
76.1200^{\circ} \mathrm{E}\end{array}$ \\
\hline 12. & Manjeri & Malappuram & Non-coastal & WM & $\begin{array}{l}11.1203^{\circ} \mathrm{N} \\
76.1200^{\circ} \mathrm{E}\end{array}$ \\
\hline 13. & Kondotty & Malappuram & Non-coastal & WM & $\begin{array}{l}11.1203^{\circ} \mathrm{N}, \\
76.1200^{\circ} \mathrm{E}\end{array}$ \\
\hline 14. & Feroke & Kozhikode & Coastal & WM & $\begin{array}{l}11.1203^{\circ} \mathrm{N}, \\
76.1200^{\circ} \mathrm{E}\end{array}$ \\
\hline 15. & Beypore & Kozhikode & Coastal & LC & $\begin{array}{l}11.1203^{\circ} \mathrm{N}, \\
76.1200^{\circ} \mathrm{E}\end{array}$ \\
\hline 16. & Puthiyappa & Kozhikode & Coastal & LC & $\begin{array}{l}11.1203^{\circ} \mathrm{N}, \\
76.1200^{\circ} \mathrm{E}\end{array}$ \\
\hline 17. & Central Market & Kozhikode & Coastal & WM & $\begin{array}{l}11.1203^{\circ} \mathrm{N} \\
76.1200^{\circ} \mathrm{E}\end{array}$ \\
\hline 18. & Nadakkav & Kozhikode & Coastal & WM & $\begin{array}{l}11.1203^{\circ} \mathrm{N}, \\
76.1200^{\circ} \mathrm{E}\end{array}$ \\
\hline
\end{tabular}


Fish Consumption and buying patterns

\begin{tabular}{|c|c|c|c|c|}
\hline 19. Vadakara & Kannur & Non-coastal & RM & $\begin{array}{l}11.1203^{\circ} \mathrm{N}, \\
76.1200^{\circ} \mathrm{E}\end{array}$ \\
\hline 20. Mahe & Kannur & Coastal & WM & $\begin{array}{l}11.7533^{\circ} \mathrm{N} \\
75.4929^{\circ} \mathrm{E}\end{array}$ \\
\hline 21. Thalassery & Kannur & Coastal & WM & $\begin{array}{l}11.8745^{\circ} \mathrm{N}, \\
75.3704^{\circ} \mathrm{E}\end{array}$ \\
\hline 22. Aayikara & Kannur & Non-coastal & RM & $\begin{array}{l}11.8745^{\circ} \mathrm{N} \\
75.3704^{\circ} \mathrm{E}\end{array}$ \\
\hline 23. Kannur Central Market & Kannur & Non-coastal & WM & $\begin{array}{l}12.0351^{\circ} \mathrm{N}, \\
75.3611^{\circ} \mathrm{E}\end{array}$ \\
\hline 24. Thaliparambu & Kannur & Non-coastal & $\mathrm{RM}$ & $\begin{array}{l}11.8745^{\circ} \mathrm{N}, \\
75.3704^{\circ} \mathrm{E}\end{array}$ \\
\hline 25. Cheruvathhor & Kasargode & Non-coastal & $\mathrm{RM}$ & $\begin{array}{l}12.2165^{\circ} \mathrm{N} \\
75.1626^{\circ} \mathrm{E}\end{array}$ \\
\hline 26. Neeleswaram & Kasargode & Non-coastal & WM & $\begin{array}{l}12.4387^{\circ} \mathrm{N}, \\
75.2012^{\circ} \mathrm{E}\end{array}$ \\
\hline 27. Kanjangad & Kasargode & Non-coastal & WM & $\begin{array}{l}12.4387^{\circ} \mathrm{N} \\
75.2012^{\circ} \mathrm{E}\end{array}$ \\
\hline 28. Kasargod & Kasargode & Non-coastal & WM & $\begin{array}{l}12.3931^{\circ} \mathrm{N} \\
75.1341^{\circ} \mathrm{E}\end{array}$ \\
\hline 29. Kumbala & Kasargode & Non-coastal & WM & $\begin{array}{l}12.3931^{\circ} \mathrm{N}, \\
75.1341^{\circ} \mathrm{E}\end{array}$ \\
\hline 30. Manathavadi & Wayanad & Highrange & $\mathrm{RM}$ & $\begin{array}{l}11.8014^{\circ} \mathrm{N} \\
76.0044^{\circ} \mathrm{E}\end{array}$ \\
\hline 31. Thazhathangadi & Wayanad & Highrange & WM & $\begin{array}{l}11.8014^{\circ} \mathrm{N}, \\
76.0044^{\circ} \mathrm{E}\end{array}$ \\
\hline 32. Kalpetta & Wayanad & Highrange & WM & $\begin{array}{l}11.6103^{\circ} \mathrm{N} \\
76.0828^{\circ} \mathrm{E}\end{array}$ \\
\hline 33. Bathery & Wayanad & Highrange & $\mathrm{RM}$ & $\begin{array}{l}11.6656^{\circ} \mathrm{N}, \\
76.2627^{\circ} \mathrm{E}\end{array}$ \\
\hline 34. Bathery Wholesale & Wayanad & Highrange & WM & $\begin{array}{l}11.6656^{\circ} \mathrm{N}, \\
76.2627^{\circ} \mathrm{E}\end{array}$ \\
\hline 35. Nilamboor & Malappuram & Non-coastal & WM & $\begin{array}{l}11.2794^{\circ} \mathrm{N}, \\
76.2398^{\circ} \mathrm{E}\end{array}$ \\
\hline 36. Manarkkad & Palakkad & Non-coastal & $\mathrm{RM}$ & $\begin{array}{l}10.6830^{\circ} \mathrm{N}, \\
76.6838^{\circ} \mathrm{E}\end{array}$ \\
\hline 37. Puthunagaram & Palakkad & Non-coastal & $\mathrm{RM}$ & $\begin{array}{l}10.6830^{\circ} \mathrm{N} \\
76.6838^{\circ} \mathrm{E}\end{array}$ \\
\hline 38. SakthanThampuran & Thrissur & Non-coastal & WM & $\begin{array}{l}10.5125^{\circ} \mathrm{N} \\
76.2194^{\circ} \mathrm{E}\end{array}$ \\
\hline 39. Chalakkudy & Thrissur & Non-coastal & WM & $\begin{array}{l}10.4730^{\circ} \mathrm{N}, \\
76.0682^{\circ} \mathrm{E}\end{array}$ \\
\hline 40. Pam Traders & Thrissur & Non-coastal & $\mathrm{RM}$ & $\begin{array}{l}10.5125^{\circ} \mathrm{N}, \\
76.2194^{\circ} \mathrm{E}\end{array}$ \\
\hline 41. Angamali & Ernakulam & Non-coastal & WM & $\begin{array}{l}10.1926^{\circ} \mathrm{N} \\
76.3869^{\circ} \mathrm{E}\end{array}$ \\
\hline 42. Aroor & Alappuzha & Coastal & WM & $\begin{array}{l}9^{\circ} .52^{\prime} 45.4^{\prime \prime} \mathrm{N} \\
76^{\circ} .18^{\prime} 12^{\prime \prime} \mathrm{E}\end{array}$ \\
\hline 43. Chandiroor & Alappuzha & Coastal & $\mathrm{RM}$ & $\begin{array}{l}9.8408^{\circ} \mathrm{N} \\
76.3087^{\circ} \mathrm{E}\end{array}$ \\
\hline 44. Cherthala & Alappuzha & Coastal & WM & $\begin{array}{l}9.67^{\prime} 41^{\circ} \mathrm{N}, \\
76.3401^{\circ} \mathrm{E}\end{array}$ \\
\hline 45. Punnapra & Alappuzha & Coastal & WM & $\begin{array}{l}9.4401^{\circ} \mathrm{N} \\
76.3434^{\circ} \mathrm{E}\end{array}$ \\
\hline 46. Kalavoor & Alappuzha & Coastal & WM & $\begin{array}{l}9.5653^{\circ} \mathrm{N} \\
76.3247^{\circ} \mathrm{E}\end{array}$ \\
\hline 47. Alappuzha Dara mkt & Alappuzha & Coastal & WM & $\begin{array}{l}9.4981^{\circ} \mathrm{N} \\
76.3388^{\circ} \mathrm{E}\end{array}$ \\
\hline 48. Thottapally & Alappuzha & Coastal & WM & $\begin{array}{l}9.3222^{\circ} \mathrm{N} \\
76.3840^{\circ} \mathrm{E}\end{array}$ \\
\hline 49. Pandalam & Pathanamthitta & Non-coastal & $\mathrm{RM}$ & $\begin{array}{l}9.2251^{\circ} \mathrm{N} \\
76.6785^{\circ} \mathrm{E}\end{array}$ \\
\hline 50. Chengannur & Pathanamthitta & Non-coastal & WM & $\begin{array}{l}9.3835^{\circ} \mathrm{N} \\
76.5741^{\circ} \mathrm{E}\end{array}$ \\
\hline
\end{tabular}

\begin{tabular}{|c|c|c|c|c|}
\hline 51. Thiruvalla & Pathanamthitta & Non-coastal & WM & $\begin{array}{l}9.3853^{\circ} \mathrm{N} \\
76.5750^{\circ} \mathrm{E}\end{array}$ \\
\hline 52. Adoor, Parakkot & Pathanamthitta & Non-coastal & WM & $\begin{array}{l}9.3835^{\circ} \mathrm{N} \\
76.5741^{\circ} \mathrm{E}\end{array}$ \\
\hline 53. Payippadu & Kottayam & Non-coastal & $\mathrm{RM}$ & $\begin{array}{l}9.4222^{\circ} \mathrm{N} \\
76.5864^{\circ} \mathrm{E}\end{array}$ \\
\hline 54. Changanassery & Kottayam & Non-coastal & WM & $\begin{array}{l}9.5916^{\circ} \mathrm{N} \\
76.5222^{\circ} \mathrm{E}\end{array}$ \\
\hline 55. Kottayam & Kottayam & Non-coastal & $\mathrm{RM}$ & $\begin{array}{l}9.4459^{\circ} \mathrm{N} \\
76.5410^{\circ} \mathrm{E}\end{array}$ \\
\hline 56. Ettumanoor & Kottayam & Non-coastal & $\mathrm{RM}$ & $\begin{array}{l}9.7138^{\circ} \mathrm{N} \\
76.6829^{\circ} \mathrm{E}\end{array}$ \\
\hline 57. Pala Fish Market & Kottayam & Non-coastal & $\mathrm{RM}$ & $\begin{array}{l}9.7131^{\circ} \mathrm{N} \\
76.6833^{\circ} \mathrm{E}\end{array}$ \\
\hline 58. Pala Fish Market & Kottayam & Non-coastal & WM & $\begin{array}{l}9.7131^{\circ} \mathrm{N} \\
76.6833^{\circ} \mathrm{E}\end{array}$ \\
\hline 59. Erattupetta & Kottayam & Non-coastal & $\mathrm{RM}$ & $\begin{array}{l}9.6858^{\circ} \mathrm{N} \\
76.7751^{\circ} \mathrm{E}\end{array}$ \\
\hline 60. Elappara & Idukki & Highrange & $\mathrm{RM}$ & $\begin{array}{l}9.6354^{\circ} \mathrm{N} \\
76.9789^{\circ} \mathrm{E}\end{array}$ \\
\hline 61. Kattappana & Idukki & Highrange & $\mathrm{RM}$ & $\begin{array}{l}9.7784^{\circ} \mathrm{N} \\
76.4505^{\circ} \mathrm{E}\end{array}$ \\
\hline 62. Kumali & Idukki & Highrange & $\mathrm{RM}$ & $\begin{array}{l}9.6051^{\circ} \mathrm{N} \\
77.1696^{\circ} \mathrm{E}\end{array}$ \\
\hline 63. Vandiperiyar & Idukki & Highrange & $\mathrm{RM}$ & $\begin{array}{l}9.5721^{\circ} \mathrm{N} \\
77.0896^{\circ} \mathrm{E}\end{array}$ \\
\hline 64. Pambanar & Idukki & Highrange & $\mathrm{RM}$ & $\begin{array}{l}9.6858^{\circ} \mathrm{N} \\
76.7751^{\circ} \mathrm{E}\end{array}$ \\
\hline 65. Mundakkayam & Kottayam & Highrange & WM & $\begin{array}{l}9.5370^{\circ} \mathrm{N} \\
76.8868^{\circ} \mathrm{E}\end{array}$ \\
\hline 66. Muttam & Idukki & Highrange & $\mathrm{RM}$ & $\begin{array}{l}9.8419^{\circ} \mathrm{N} \\
76.7423^{\circ} \mathrm{E}\end{array}$ \\
\hline 67. Thodupuzha & Ernakulam & Non-coastal & WM & $\begin{array}{l}9.5132^{\circ} \mathrm{N} \\
76.6239^{\circ} \mathrm{E}\end{array}$ \\
\hline 68. Muvattupuzha & Ernakulam & Non-coastal & WM & $\begin{array}{l}9.9894^{\circ} \mathrm{N} \\
76.5790^{\circ} \mathrm{E}\end{array}$ \\
\hline 69. Manjeswaram & Kasargode & Non-coastal & $\mathrm{RM}$ & $\begin{array}{l}12.7246^{\circ} \mathrm{N}, \\
74.8850^{\circ} \mathrm{E}\end{array}$ \\
\hline 70. Perumbavoor & Ernakulam & Non-coastal & $\mathrm{RM}$ & $\begin{array}{l}10.1789^{\circ} \mathrm{N}, \\
76.1697^{\circ} \mathrm{E}\end{array}$ \\
\hline 71. Aluva & Ernakulam & Non-coastal & WM & $\begin{array}{l}9.9389^{\circ} \mathrm{N} \\
76.2626^{\circ} \mathrm{E}\end{array}$ \\
\hline 72. Munambam & Ernakulam & Coastal & LC & $\begin{array}{l}10.1789^{\circ} \mathrm{N}, \\
76.1697^{\circ} \mathrm{E}\end{array}$ \\
\hline 73. Varapuzha & Ernakulam & Coastal & RM & $\begin{array}{l}9.9792^{\circ} \mathrm{N} \\
76.2773^{\circ} \mathrm{E}\end{array}$ \\
\hline 74. Chambakkara & Ernakulam & Coastal & WM & $\begin{array}{l}9.9792^{\circ} \mathrm{N} \\
76.2799^{\circ} \mathrm{E}\end{array}$ \\
\hline 75. Broadway & Ernakulam & Coastal & RM & $\begin{array}{l}9.9792^{\circ} \mathrm{N} \\
76.2795^{\circ} \mathrm{E}\end{array}$ \\
\hline 76. Kaloor & Ernakulam & Coastal & $\mathrm{RM}$ & $\begin{array}{l}9.9971^{\circ} \mathrm{N} \\
76.3028^{\circ} \mathrm{E}\end{array}$ \\
\hline 77. Sakthikulangara & Kollam & Coastal & LC & $\begin{array}{l}8.9230^{\circ} \mathrm{N} \\
76.5527^{\circ} \mathrm{E}\end{array}$ \\
\hline 78. Valiyathura & Trivandrum & Coastal & LC & $\begin{array}{l}8.4646^{\circ} \mathrm{N} \\
76.9276^{\circ} \mathrm{E}\end{array}$ \\
\hline 79. Vizhinjam & Trivandrum & Coastal & LC & $\begin{array}{l}8.3932^{\circ} \mathrm{N} \\
77.0046^{\circ} \mathrm{E}\end{array}$ \\
\hline 80. Pangode & Trivandrum & Coastal & WM & $\begin{array}{l}8.5038^{\circ} \mathrm{N} \\
76.9830^{\circ} \mathrm{E}\end{array}$ \\
\hline 81. Palayam & Trivandrum & Coastal & $\mathrm{RM}$ & $\begin{array}{l}8.5039^{\circ} \mathrm{N} \\
76.9511^{\circ} \mathrm{E}\end{array}$ \\
\hline 82. Kavanadu & Kollam & Coastal & WM & $\begin{array}{l}10.0133^{\circ} \mathrm{N}, \\
76.3350^{\circ} \mathrm{E}\end{array}$ \\
\hline
\end{tabular}




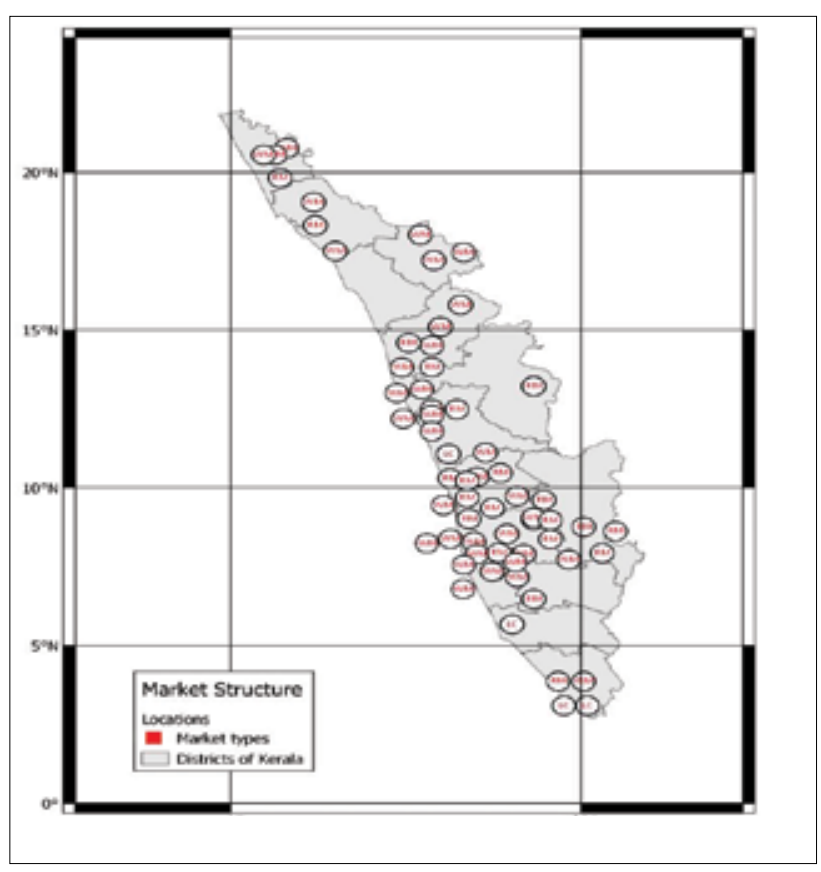

Fig. 1. Study area - Districts surveyed across Kerala

were surveyed across these districts. Purposive and Simple random sampling technique was used to collect data from 355 respondents. All the markets were directly visited and information on different consumer attitudes towards fish consumption and preference to choose markets were analysed. Among the 355 respondents, 274 are male and 81 are female, and the respondents were firmly preferred to be the fish consumers. The datasets obtained through the survey was analysed using descriptive statistical analysis as frequencies and percentage to infer the results.

\section{Results and discussion}

\section{Socio-Demography of the respondents}

From the 355 respondents, $77 \%$ constitutes male and 23\% are female respondents (Table 2 ) and the significant rejoinders articulated by the respondents were framed in this article. The respondents are the fish consumers of the locality who constrict their fish buying from the confined markets of the study region. The highest proportions of respondents are males and the involvement of females was noted to be relatively less. This was due to the state of apprehension towards participation in the survey. Age brackets of the respondents ranged from 25 to 60 years.

\begin{tabular}{lll} 
Table 2. Percentage variation in respondents \\
\hline Total No. of Respondents & $(\mathrm{n}=355)$ & $\%$ \\
\hline Male & 274 & 77.18 \\
\hline Female & 81 & 22.82 \\
\hline
\end{tabular}

\section{Fish Marketing System in Kerala}

In the current study, the fish marketing was noted as frontal commercial zone with multiple functionaries such as wholesalers, commission agents, retailers, auctioneers, traders and consumers. Some of the fish markets are well-built structures fabricated and registered by the state government and other funding agencies such as Department of Fisheries, National Fisheries Development Board (NFDB), Non-government organisations, Fisher co-operative societies, etc. These organisations provide funds for developments in processing and post-harvest technology transfer for storage, icing and other related infrastructures. With contrast to these registered structured markets, way-side stalls across the roadsides were put upon by the local natives/ middlemen. The current study defines these "way-side stalls as way-side markets which are short-stint markets in time and function with below par hygienic conditions and low value-addition infrastructure located on the platforms of the roads". These markets don't offer a permanent structure making it cheaper in terms of construction cost and is operational based on the fish arrivals sourced from different landing centres/ wholesale agents on a day to day basis. Furthermore, these markets maximise the consumer preferences with marginalised magnitudes of price to the consumers. These shifts in consumer preferences towards both the markets were attempted to be studied in detail and are presented in this article.

While studying the establishments of domestic fish markets in remote areas of Kerala, it was noted that these domestic markets play a crucial role in fish trade across the far-flung locations. The study covered 82 well-structured domestic fish markets across the Kerala state which is categorised into three, based on their geographical settings: 1. Coastal-region markets (30), 2. Non-coastal region markets (40) and 3. High-range markets (12). From the marketing functionaries and the market linkages, the markets are classified into three: 1 . Wholesale markets, 2. Retail markets and 3. Landing centre markets. The total number of markets surveyed from each district is presented in the Fig. 2. About $56 \%$ of the markets surveyed are wholesale, $37 \%$ are retail and $7 \%$ are landing centre markets. In total, the higher number of markets was covered from two

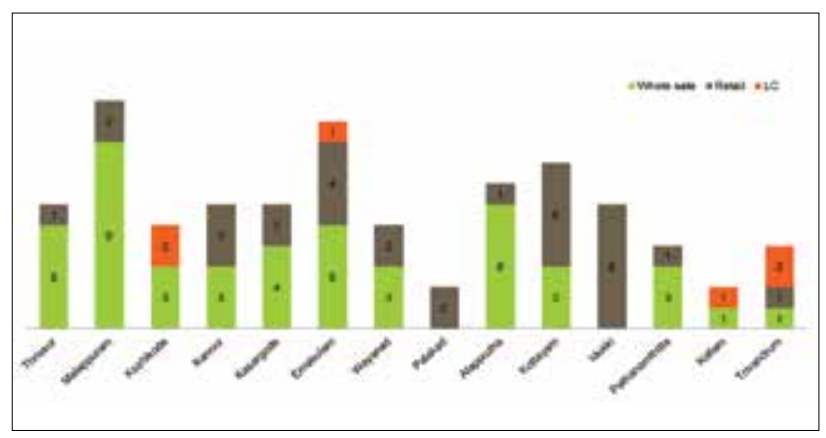

Fig. 2. Types of fish markets surveyed of Kerala 
districts, Malappuram (11) and Ernakulam (10) districts. The markets studied are time-honoured years back and are precisely controlled by state fisheries departments, local self-governing bodies such as municipal corporations, fishermen cooperative societies, non-government organisations dealing with fishers, state fisheries corporations/State fishermen federation, Self Help Groups, corporate bodies and private entrepreneurs. These markets sell both marine and inland fish species through multiple marketing chains of wholesale, major, minor retailers, auctioneer, etc. In the recent years, balanced fish distribution systems to the remote areas are reasonable due to the improved storage infrastructures and transportation potentials empowered by the marketing functionaries.
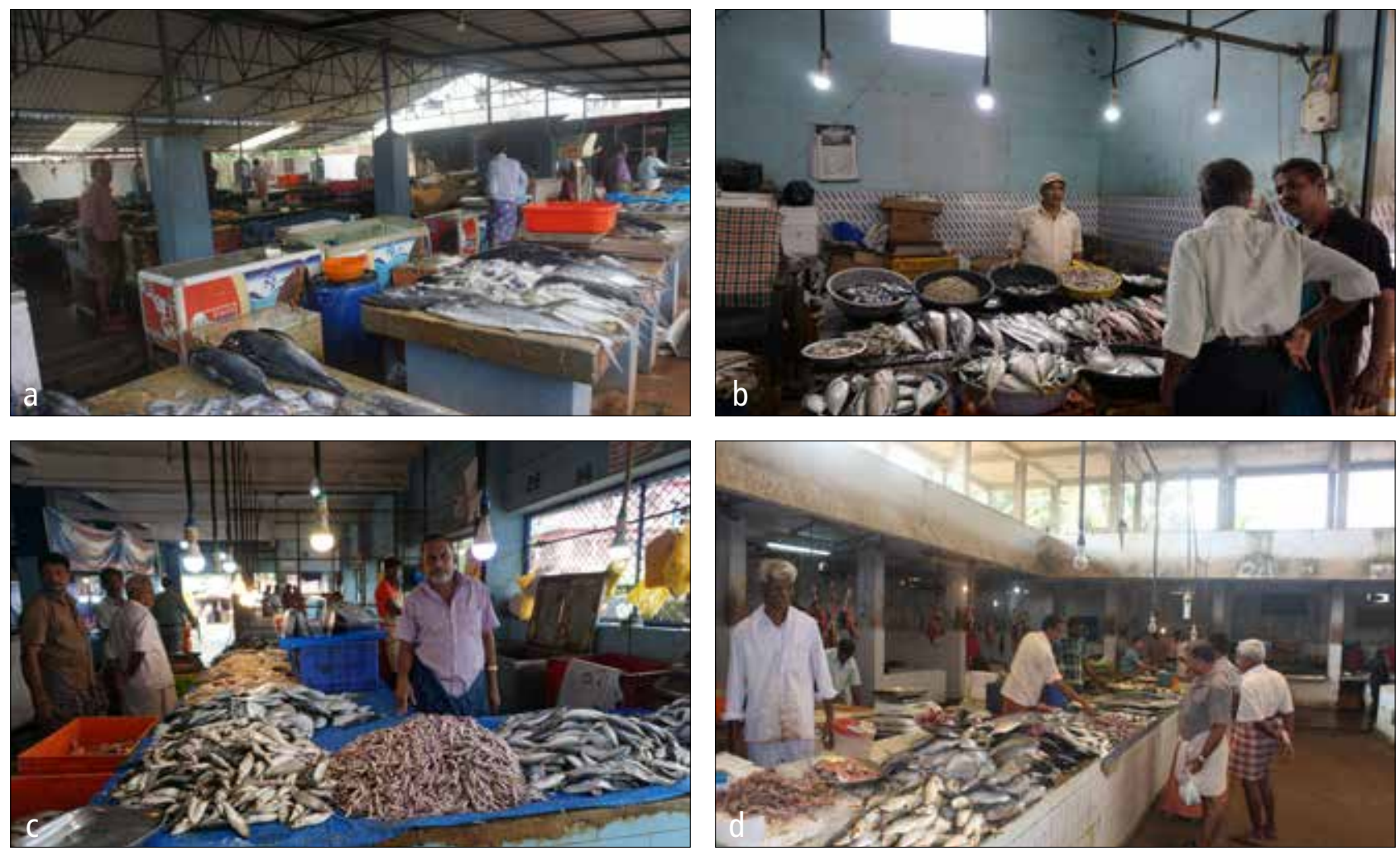

Fig. 3a. Structured markets at different locations of Kerala a. Alapuzha b. Aluva c. Etumanoor d. Kondotty
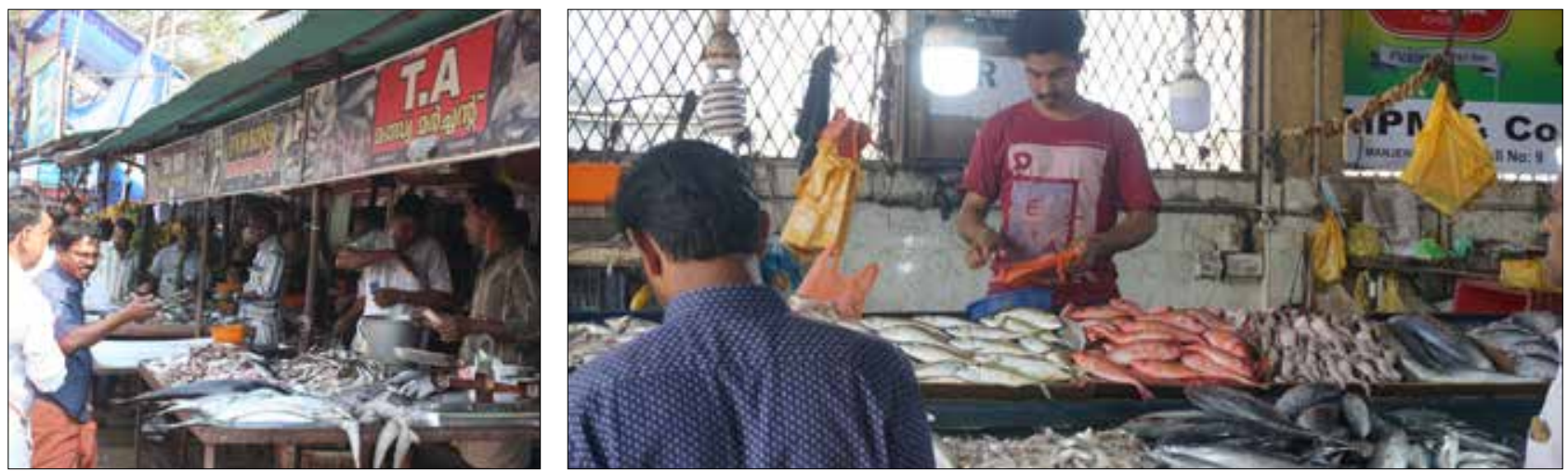

Fig. 3b. Way-side fish stall/markets 
the unhygienic waste disposal environment on the roads was noted to be the significant constraints of these way-side stalls.

\section{Factors influencing fish purchase and consumption behaviour}

In this section, the buying and selling patterns and behaviours of consumers towards species and market preferences were assessed and presented. Preference level towards fish species and choosing a market to buy fish is a mental state and has no any connotation with consumption (Palash and Sabur, 2004). However, the interest to buy a species is more and more influenced by individual's internal factors. The respondents enunciated that the preferences for fish procurement are from the two major outlets: well-structured markets and way-side markets. $65 \%$ of the respondents stated that they intend to buy fish while travel on the way or back to home. This is because the way-side markets are easier in accessibility with less cost and their choice of buying fish is either premeditated or immediate. The common and collective factor observed from all the respondents is that they consider time as a crucial factor to buy fish with its quality of freshness and taste. Fishes, which reach these way-side stalls are said to be available from 6.30 to $9.00 \mathrm{hrs}$ in the morning and 3.00 to $9.00 \mathrm{hrs}$ in the evening. The respondents are aware of the perishable nature of fishes and lack of proper storage facility to keep it fresh in the way-side stalls. To understand the buying behaviour of the respondents, conversations on time of shopping was probed. Early morning hours were marked to be the best purchasing time by the respondents. This statement substantiates that the consumers/ buyers are aware and conscious about the quality of the fishes during their purchase. Further to the taste, quality and nutritional value, some of the other significant factors determining the decision to buy fish as expressed by the consumers are availability of fish species, size of fishes, price variability, easy prepare and cooking time. These factors

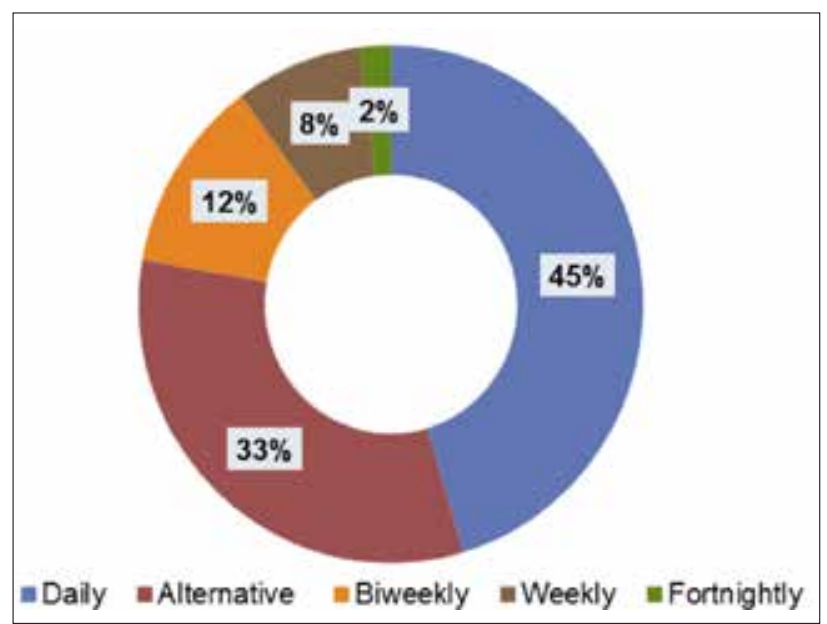

Fig. 4. Frequency of fish consumption were also described as the market determinant attributes by Ahmed et al., 2011.

During the field observations, few way-side stalls in conjunction to the well-structure retail markets and whole-sale markets were noted. From the 355 respondents, the rate of fish consumption was higher for daily-fish eaters (161) and alternative-day fish eaters (115). The dialects on desire of respondents towards buying fish while travel and travelling to buy fish was recorded from all the respondents. Fish Consumption range (frequency) varies among the 355 respondents, $45 \%$ of the consumers are daily fish-eaters, $33 \%$ are alternative day fish consumers, followed by biweekly (12\%), weekly (8\%) and fortnightly $(2 \%)$ (Fig. 4).

\section{Species preference and Source of procurement}

The source of fish buying (Fig. 5) among the consumers deviates and the preferences of fish purchase among the respondents were higher from the retail markets (179) followed by way-side stalls (80) and vendors (71). The preference for purchase was low from the landing centre and wholesale markets for the distance to be travelled and the minor quantities they would purchase. Even though the prices tend to be lower in these markets compared to the domestic retail and way side markets they wouldn't trade smaller quantities for sale. This upturned our interests on relating the functioning strategies and buyer-seller paradigms across the well-structured domestic fish markets and way-side stalls across the study region.

Generally, the well-structured domestic fish marketing systems are driven seamless with the marketing structures such as potable water availability, quality icing, uninterrupted electricity, efficient waste disposal system, etc. In contrast to the domestic markets selling multiple commodities, there are 4-5 short stint wayside stalls situated in every location which will be functioning for 3-4 hours with or without proper authorisation from the government. These way-side stalls operate mostly daily during

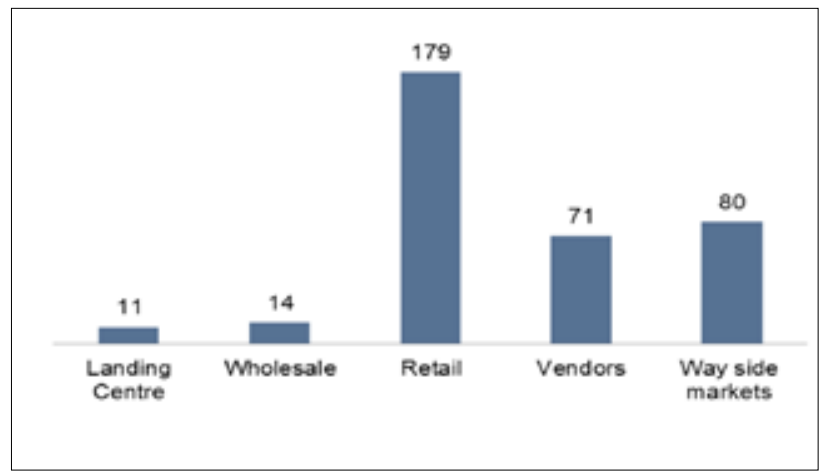

Fig. 5. Source of fish procurement 
Table 3. Dominant species observed in the markets during the survey and their source of purchase

\begin{tabular}{llll}
\hline Species & Market Name (Vernacular) & Resource & Source of purchase \\
\hline Sardines & Chaala & Marine & Whole sale, Retail, Way side \\
\hline Mackerel & Ayila & Marine & Whole sale, Retail, Way side \\
\hline Snapper & Kilimeen & Marine & Whole sale, Retail \\
\hline Squids & Kanava & MNC, HR \\
\hline Prawns & Chemmeen & Whole sale, Retail \\
\hline Carangids & Kera & Marine & Whole sale, Retail \\
\hline Scomberoids & Ney meen & Marine & Whole sale, Retail \\
\hline Tuna & Choora & Marine & Whole sale, Retail \\
\hline Tilapia & Tilopia, Thilopia, & Whastal \& NC, HR \\
\hline Cat fish & Etta,Valiaetta, Kaari & Inland & Coastal \& NC, HR sale \\
\hline
\end{tabular}

morning and evening hours. Most of these cases the way side markets do not pay any charges for its fish trade operations.

Fishes from different landing centres/ wholesale markets are transported to these locations through trucks by dawn of each day. Fish buying has become more impulsive due to the increased consumption rate of about $9 \mathrm{~kg}$ in India (Borah, 2019). Despite the fact, analysing the fish buying behaviours from these markets, both low value and high value fishes are traded in the same frames. However, preferences of the local people towards choosing way-side stalls are for low-value fishes such as sardine, mackerels, cat-fish, and pearl-spot. When their inclination gets shifted to the high-value fishes, well-structured domestic markets emanate into their picture. This states the quantum of low value fishes is high in the way-side stalls rather than other markets. These perceptual dispositions on decreased profit levels in the well-structure markets raise conflict drifts between the sellers of the way-side and well-structured domestic markets. Table 3 displays the dominant species purchased by the buyers and the source of procurement of different species from different markets. Tilapia, tuna and small pelagics such as sardine and mackerel were bought from the short-stint wayside stalls. However, during the survey, sardines were found to low in quantity and the preferences of the consumers were towards the way-side stalls for freshwater fishes. Seer fishes, prawns, tuna and some species of carangids were of higher value and the consumers always desired and were impulsive for selected, identified and known traders of well-structured markets for obtaining these high value fishes.

\section{Marketing channels of the domestic fish markets}

Marketing channels are the routes through which the consumers meet their necessities through multi-functionaries. The coastal area markets are well-known to be most operative with multilevel intermediaries and marketing functionaries. While, the marketing channels of remote areas/ high range markets are poorly studied on their organisation and efficiency. With this emphasis, the current study enumerated the different marketing channels functioning in the registered well-structured markets and way-side stalls of Kerala. Major intermediaries and the marketing channels observed in the high range areas are whole salers (Primary and Secondary), retailers, established traders, the local way-side traders and consumers. The marketing channels of the registered and unregistered markets identified are represented in the Figure 6 . The primary source noted is the landing centre markets which are active in the harbour/ landing areas of coastal regions. Market arrivals to the wholesale/retail intermediaries are from the coastal landing centres of Kerala and other neighbouring states such as Karnataka, Tamil Nadu and Andhra Pradesh. The fish arrivals from the primary source such as landing centres are lively from 12.00 to $2.00 \mathrm{hrs}$ in the mid-night. The fishes from the landing areas enter into the major intermediaries such as whole salers (Primary and Secondary) and retailers at 4:00 hrs in the morning through air-conditioned maxi trucks used for transporting fresh fish to well-structured registered fish markets. Conversely, the low-value fishes such as sardines, mackerel and tilapia from riverine areas/farms were dominantly transported from these whole-sale and retail markets through mini-trucks to the way-side traders by 6.00 to $7.00 \mathrm{hrs}$. On an average, about $1000 \mathrm{~kg} /$ day of iced both marine and freshwater fishes were carried to these areas. The

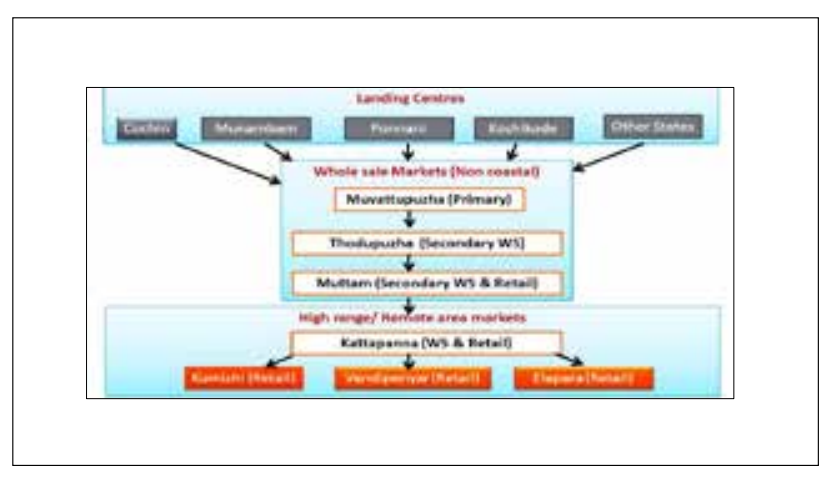

Fig. 6. Marketing channel of the domestic fish markets of Kerala identified during the study 
observations on marketing channels of the way side markets states that fish as a commodity traded to high-range way-side sellers. Despite the fact of loss of quality until the consumption time, the infrastructure and storage facilities of way-side stalls are lacking thereby reducing the post-harvest loss of fishes. The below flow chart depicts the market functionaries and channels of way-side stalls at select locations of high-range areas.

As like other states, the fish markets of Kerala state also experience notable constraints and limitation in the market structure and functioning. As reported by Upadhyay et al. (2017) involvement of several marketing intermediaries should be limited/regulated to reduce the diminishing producers share in consumers' rupee. The market intermediaries continuous as "necessary evils" ensuring supply patterns and demand creation towards fish distribution and consumption (Shyam, 2016). The state government should take necessary steps to regulate proper price monitoring system in markets.

Typical well-structured domestic fish markets encounter broader expenditure patterns and implicit costs in minimizing post-harvest losses, increased revenue, providing employment opportunities and offers high standards of hygiene and sanitation leading to food safety. In the paradox of modernising markets with sophisticated infrastructure and facilities for post-harvesting techniques and value-additions of the products will only represent as a structural auxiliary to the well-structured domestic fish markets in these interior areas. However, without these accessory components in the way-side fish stalls, fish trade was earning good profit rate to the sellers in tote with the wellstructured domestic markets. These conditions acclaims that, the government should pay attention to refine regulations on converting these way-side stalls into stalls inside the sedentary well-structured domestic fish markets to avoid huge losses suffered by the structured domestic marketers. This could also reduce the overhead costs met by the way-side marketers. More of trade related regulations, taxes and all added-functions and a well-developed domestic marketing system with promotion of extra stalls for way-side stalls should be taken into account thereby ensure the viability of the fish marketing sector in the remote areas and high range areas of the region.

\section{Acknowledgements}

The authors are thankful to the Director, Central Marine Fisheries Research Institute, Kochi for the extended support.

\section{References}

Ahmed, A. F., Z. Mohamed and M. M. Ismail. 2011. Determinants of Fresh Fish Purchasing Behavior Among Malaysian Consumers. Curr. Res. J. Soc. Sci., 3:126131.

Aswathy, N., S. Salim, V. P. Vipinkumar and R. Narayanakumar. 2017. Price behaviour, marketing channels and efficiency of marine fish marketing in Karnataka. Mar. Fish. Infor. Serv. T E Ser., 15-17 p.

Borah, B. C. 2019. Small Indigenous Freshwater Fish Species in Nutrition of Ethnic Population of North East India. Acta. Sci. Nutr. Heal., 3:158-167.

Kumar, B. G., K. K. Datta and P. K. Joshi. 2008. Domestic Fish Marketing in IndiaChanging Structure, Conduct, Performance and Policies. Agric. Econ. Res. Rev., 21:345-354.

Palash, M. S. and S. A. Sabur, 2004. Consumption pattern and consumer behaviour of fish in Dhaka city. J. Bangladesh Agri. Univ., 2:361-370.

Sathiadhas, R. and R. Narayanakumar. 1994. Price Policy and Fish Marketing System in India. Biol. Educ., 225-241pp.

Shyam, S. Salim and R. M. Rahman. 2014. Market structure analysis of fish markets in Ernakulam district. Mar. Fish. Infor. Serv, T\& E Ser., 220:22-2.

Shyam, S. Salim, Rahman M. Ramees, K. N. Pushkaran M. Nashad and S. Soma. 2015. Fish Marketing-A Market Structure Analysis of Kozhikode and Alappuzha districts. Mar. Fish. Infor. Serv, T\& E. Ser. 223-24:18-23.

Shyam, S. Salim, P. K. Safeena and N. R. Athira. 2015. Does India Really Need to Export Fish: Reflections and Upshots. Agricultural Economics Research Review, 28. 117-125.

Shyam, S. Salim. 2016. Fish consumption pattern in India: Paradigm shifts and Paradox of export trade (Fish consumption pattern in India, exports-Overview). Food and Beverage News. 25-28 p.

Upadhyay, A. D, Jagpal, P. D. Roy. 2017. Structural performance of fish market and socio-economic status of market functionaries of Naveen Machhali Mandi Mahanva of Gorakhpur, Uttar Pradesh. Econ. Aff., 61:511 p.

Vanhonacker, F., Z. Pieniak and W. Verbeke. 2010. Fish market segmentation based on consumers' motives, barriers and risk perception in Belgium. J. Food. Prod. Mark. 16:166-183. 